\title{
The Osteoclast in Bone Metastasis: Player and Target
}

\author{
Antonio Maurizi and Nadia Rucci * \\ Department of Biotechnological and Applied Clinical Sciences, University of L'Aquila, 67100 L'Aquila, Italy; \\ antoniomaurizi@outlook.com \\ * Correspondence: nadia.rucci@univaq.it; Tel.: +39-0862-433525; Fax: +39-0862-433523
}

Received: 1 June 2018; Accepted: 21 June 2018; Published: 27 June 2018

\begin{abstract}
Bone metastases are frequently the final fate of breast and prostate cancer patients. According to the definition of metastasis as an incurable disease, to date there are no effective treatments for tumor-associated bone metastases and this represents a real challenge for the researchers in the field. The bone is a heterogeneous environment that represents a fertile soil for tumor cells, supporting their growth. Among the different cell types present in the bone, in this review we will focus our attention on the osteoclasts, which are crucial players in the so called "vicious cycle", a phenomenon triggered by tumor cells eventually leading to both tumor proliferation as well as bone deregulation, thus fueling the development of bone metastasis. The complex network, linking tumor cells to the bone by activating osteoclasts, represents a fruitful target for the treatment of bone metastases. In this review we will describe how tumor cells perturb the bone microenvironment by actively influencing osteoclast formation and activity. Moreover, we will describe the current antiresorptive drugs employed in the treatment of bone metastases as well as new, targeted therapies able to affect both cancer cells and osteoclasts.
\end{abstract}

Keywords: breast cancer; bone metastases; osteoclasts; antiresorptive drugs; vicious cycle

\section{Bone Metastases: Pathological Features}

Metastasis is, so far, an incurable disease. The skeleton is one of the most frequent sites of metastases, behind the lungs and liver [1]. Prostate and breast cancers are responsible for the majority of bone metastases. Indeed, in prostate cancer the bone is often the unique site of metastasis, with a prevalence of up to $90 \%$, while for breast cancer the prevalence is around $65 \%-75 \%$. Notably, the median survival of breast cancer patients who develop bone metastases is twenty months, while it dramatically drops to six months in case of lung metastases and further to three months in patients experiencing liver metastases [2]. The median survival of prostate cancer patients with bone metastases is better, at around 53 months [3]. Therefore, in breast and prostate cancers, those patients with unique metastases in the bone represent as a distinct subset of metastatic patients with a better prognosis than those with liver or lung metastases. Moreover, in bone-only metastatic patients there is usually a multifocal dislocation of the lesions, which mainly affect the sternum, pelvis and lumbar spine [4]. Unfortunately, almost $50 \%$ of breast cancer patients with bone metastases are destined also to develop metastases in soft tissues.

Patients with bone metastases experience a very miserable quality of life, due to severe pain, spinal cord compression, fractures, bone marrow aplasia and hypercalcemia, the latter being the principal cause of death. In fact, hypercalcemia can induce gastrointestinal dysfunctions, as well as constipation, polyuria and fatigue. In the advanced stage, it is the leading cause of renal failure and cardiac arrhythmias [5]. All these symptoms are usually classified as skeletal-related events (SREs).

Despite some cases of bone metastases being asymptomatic and causing damage to bone structure without causing pain [6], the development of bone pain is usually highly indicative of 
bone metastases [7]. The pain associated with bone metastases could be of inflammatory or mechanical origin; inflammatory pain is due to the local release of cytokines and chemical mediators by the tumor cells, thus stimulating intraosseous nerves. Mechanical pain is caused by the pressure exerted by tumor mass within the bone, associated with loss of bone strength. Although they are not effective in increasing survival, current antiresorptive agents and radiotherapy reduce bone pain, thus significantly improving patient's quality of life [8].

At diagnosis, bone metastases can be classified, according to their radiological appearance, as osteolytic, osteosclerotic or mixed, the latter when both features are present in the same region. Osteolytic lesions are preferentially caused by breast cancer cells and are characterized by the complete destruction of bone and its substitution with a tumor mass. Since the bone is a hard tissue, this destruction seems to be necessary for tumor cells to make space for their growth. The first theories explained bone destruction as the result of a physical compression caused by tumor cell growth, while other scientists hypothesized an acquired capacity of tumor cells to reabsorb the bone. Indeed, over the years a univocal consensus has been reached on the fact that the exacerbated bone resorption is the result of the ability of tumor cells to induce osteoclastogenesis, that is the formation of the cells devoted to resorbing bone [9].

Osteosclerotic (i.e., osteoblastic) metastases are instead characterized by apposition of new bone of poor quality that is secreted by the osteoblasts because of a conditioning by tumor cells. Moreover, osteosclerotic metastases are usually preceded, and likely triggered, by an exacerbated osteoclast activation. This also explains why the current antiresorptive therapies are effective also in this type of bone metastasis.

Whichever histopathological kind of bone metastases, all are determined by a deregulation of bone homeostasis caused by tumor cells.

\section{Bone Physiology}

As described by Stephen Paget more than 100 years ago with the "seed and soil" theory [10], tumor cells can only root themselves in those distant organs where they find the appropriate conditions to grow, thus explaining why breast cancer cells preferentially metastasize the bone. This tissue has a peculiarity that is the ability to continuously renew itself through a physiological process called bone remodeling. This is important to guarantee good quality of the bone, the repair of microfractures and the homeostasis of calcium [11].

\subsection{Bone Remodeling: The Virtuous Cycle}

Bone cells, that is osteocytes, osteoblasts and osteoclasts, actively participate in the cycle of bone remodeling, following space and time well-controlled steps, as described:

Activation phase. The starting point of bone remodeling is triggered by physiological and/or pathological stimuli. Osteocytes, the bone cells buried in the bone matrix, having mechano-sensorial functions, can promote the activation phase following the perception of changes in mechanical loading. Other inputs can come from micro-fractures or the release of cytokines, like insulin-like growth factor (IGF), tumor necrosis factor (TNF) $\alpha$, parathyroid hormone (PTH) and interleukin (IL) 6, which in turn promote the detachment of the lining cells (i.e., quiescent osteoblasts) from the bone surface and the exposition of the latter for the subsequent step of erosion [12]. During this phase there is also attraction of osteoclast precursors from the blood and their fusion and differentiation into multinucleated osteoclasts.

Resorption phase. Polarized multinucleated osteoclasts firmly adhere to the bone surface by the so-called sealing zone and start to dissolve the bone. This phase is relatively fast compared to the others of the cycle of remodeling, lasting 2 weeks. It ends because of the activation of osteoclast apoptosis, thus ensuring that excess resorption does not occur.

Reverse phase. This phase is so named because of the involvement of reverse cells, whose role has not yet been completely clarified. These are macrophage-like cells with a likely function of removal 
of debris produced during bone degradation, thus preparing the bone for the anabolic action of osteoblasts. Moreover, these cells receive signals that allow the coupling of bone resorption bone formation activities $[13,14]$.

Formation phase. As a consequence of bone resorption, there is the release of several factors usually stored in the bone matrix, including bone morphogenetic proteins (BMPs), fibroblast growth factors (FGFs), and transforming growth factor (TGF) $\beta$, which are chemoattractants for osteoblasts in the reabsorbed area. This is the longest phase of the remodeling, lasting 4 months, during which the osteoblasts produce new bone matrix, initially not calcified (osteoid) and then allow its mineralization, through the deposition of hydroxyapatite crystals amongst the collagen fibrils. This is a well-controlled process relying on a fine tune regulation of the local calcium and phosphate concentrations and the ratio of inorganic pyrophosphate to phosphate [15]. The complete formation and mineralization of the previously resorbed bone matrix leads the osteoblasts to the following possible fates: undergo programmed cell death, become a bone-lining cell or remain "buried alive" within the bone matrix thus becoming osteocytes.

Correct bone homeostasis strictly relies on a perfect equilibrium between osteoblast and osteoclast functions. Deregulation of osteoclast activity is a key event in the development of bone metastases, therefore in the next paragraph we will illustrate in more detail the physiology of this cell, and how it has become the best therapeutic target for the treatment of bone metastases.

\subsection{Biology of the Osteoclast}

Osteoclasts are multinucleated cells that resorb the bone matrix keeping the skeleton healthy by ensuring bone turnover [16]. They arise from the monocyte-macrophage lineage under the stimulation of two pivotal cytokines: macrophage-colony stimulating factor (M-CSF) and receptor activator of nuclear factor kappa- $\beta$ ligand (RANKL), both mainly produced by osteoblasts in the bone, thus actively participating in the regulation of osteoclast formation. Osteoclast differentiation transpires to be a complex process that can be divided in three major steps: (1) the commitment of the hematopoietic stem cells (HSCs) towards the macrophages lineage; (2) the acquisition of the positivity for the tartrate resistant acid phosphatase (TRAcP) enzyme and calcitonin receptor, thus giving rise to an osteoclast precursor and (3) the fusion of the osteoclast precursors eventually forming to mature polynucleated osteoclasts (Figure 1).

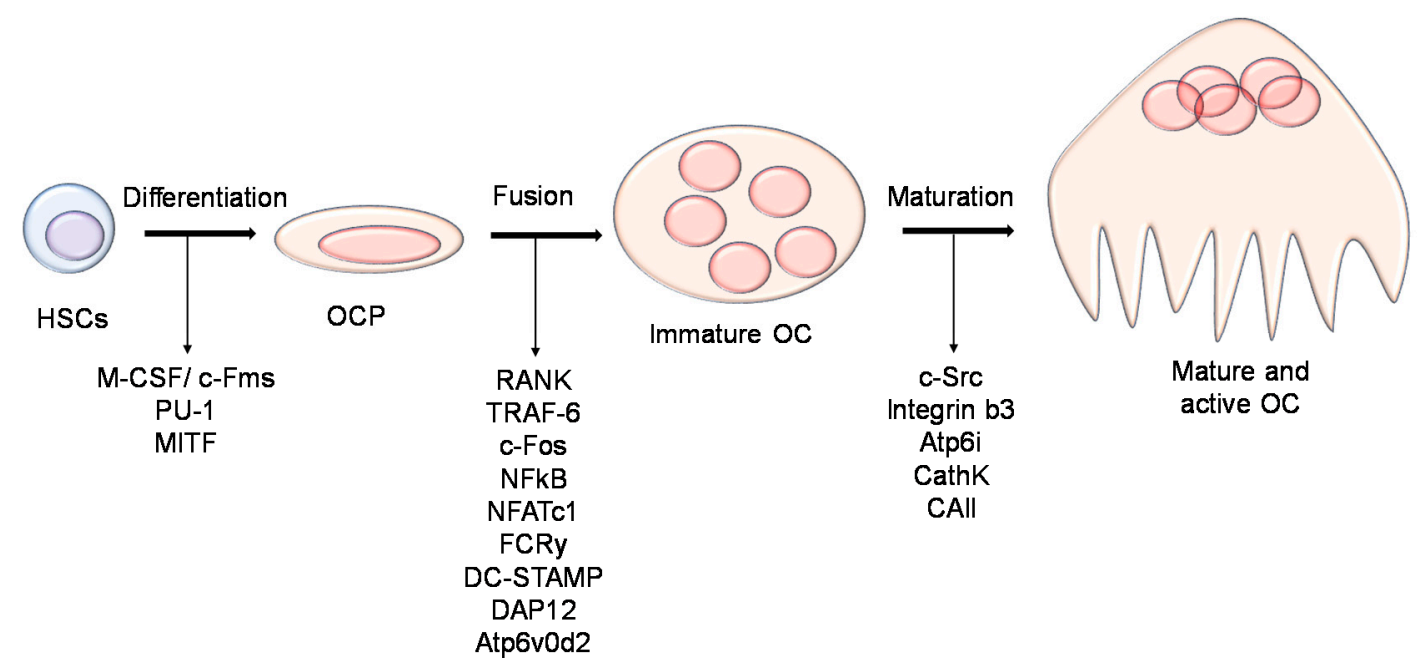

Figure 1. Osteoclast formation and differentiation. Cartoon illustrating the different steps and molecules involved in the osteoclast differentiation from the hematopoietic stem cells towards the mature osteoclast. HSCs: hematopoietic stem cells; OCP: osteoclast precursor; OC: osteoclast. 
Going more deeply into the molecular mechanism underlying osteoclast differentiation, the story becomes more complex (Figure 2). M-CSF enhances the proliferation and survival of preosteoclasts [17]. The understanding of its role became clear after the finding that mice lacking functional M-CSF (i.e., op/op mice), or knockout for the M-CSF receptor ( $\mathrm{csfr}^{-/-}$mice), displayed an osteopetrotic phenotype due to the complete lack of osteoclasts [18]. Another important role played by M-CSF is to elicit the expression of RANK receptor by osteoclast precursors [19].

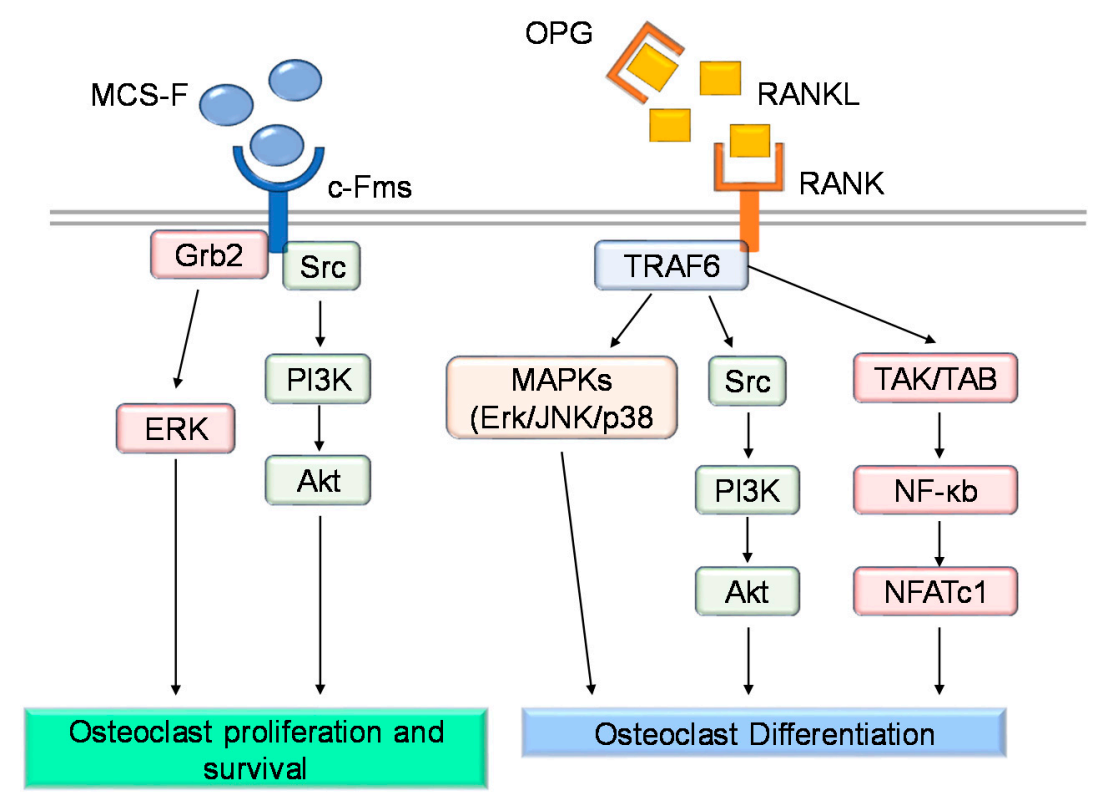

Figure 2. Molecular pathways involved in osteoclast proliferation, differentiation and survival. Cartoon illustrating the main intracellular pathways involved in osteoclast survival and differentiation.

RANKL/RANK signaling is pivotal for osteoclast differentiation [20,21]. Within the bone, RANKL is mainly produced by stromal cells, osteoblasts and osteocytes [22]. Osteoblasts also produce osteoprotegerin (OPG) that acts as a decoy receptor for RANKL, inhibiting its binding to RANK expressed by the osteoclast precursors [21,23]. Thus, OPG is considered a negative regulator of osteoclast differentiation [20]. Both RANK- and RANKL-deficient mice show a severe osteopetrotic phenotype, caused by defective osteoclast formation [24-26]. On the other hand, a mouse model lacking OPG showed an overall reduction of the bone density due to increased osteoclast differentiation [27]. Activation of RANKL/RANK signaling induces the recruitment of TRAF6 (TNF Receptor Associated Factor 6), which in turn allows the activation of the Nuclear Factor Kappa B (NF-kB) transcription factor, which translocates into the nucleus and promotes the transcription of genes regulating osteoclast differentiation. Finally, RANKL-mediated NF- $\mathrm{KB}$ and c-fos activation enable the recruitment of NFATc1 (Nuclear Factor of Activated T-cells Cytoplasmic 1), which is essential for complete osteoclast differentiation [28]. NFATc1 stimulates the expression of osteoclast-specific genes, including the calcitonin receptor, TRAcP, Cathepsin K, OSCAR and $\beta 3$ integrin [29-32].

Another crucial step of osteoclast differentiation is the fusion of the osteoclast precursors. This process is mediated by several molecules, including integrins, the proto-oncogene c-src, E-cadherin, DC-STAMP (dendritic cell-specific transmembrane protein), ADAM (a disintegrin and metalloproteinase) family proteins, the macrophage fusion receptor (MFR) and the V0 subunit $\mathrm{d} 2$ of the V-H+-ATPase [33-37].

\subsubsection{Osteoclast Function}

A mature osteoclast is a multinucleated and polarized cell, in which it is possible to identify specific membrane domains reflecting specific functions (Figure 3). In the apical membrane there 
is a "sealing zone" that contains two distinct areas called the "sealing membrane" and the "clear zone" [16]. The "sealing membrane" is a bone-facing membrane portion including adhesion structures called podosomes [38]. These are made by actin microfilaments, adhesion molecules, adapter and signaling proteins, that during bone resorption are essential for the formation of peripheral hoops called actin rings [39]. Moreover, the integrin receptors $\alpha_{2} \beta_{1}, \alpha_{v} \beta_{3}$ and $\alpha_{v} \beta_{5}$, anchor the osteoclast to the extracellular matrix. This tight adhesion is mandatory for osteoclast activity, thus sealing the portion of the bone matrix to be degraded. Adjacent to the "sealing zone" is the "ruffled board", a peculiar membrane structure consisting of several membrane expansions [40]. Here, the lysosomal membranes fuse with the osteoclast membrane allowing the release of lysosomal enzymes that will digest the organic part of the matrix. Moreover, the ruffled board contains transporters essential for the release of ions, mainly chloride and protons, and for the re-uptake of the resorbed materials from the resorption lacuna. Moving further from the bone surface we encounter the basolateral membrane domain that is in contact with the vascular compartment and presents several ion transporters [41]. Recently, novel specialized subdomains have been described [42]. In particular, the ruffled board presents a "fusion zone" and an "uptake zone" that are involved in the endo/lysosome vesicular fusion, the re-uptake of digested bone matrix and recycling of the lysosomal enzymes [42,43]. Moving to the basolateral membrane, a "functional secretory domain" is present, which is essential for releasing the digested matrix components into the blood stream [43].

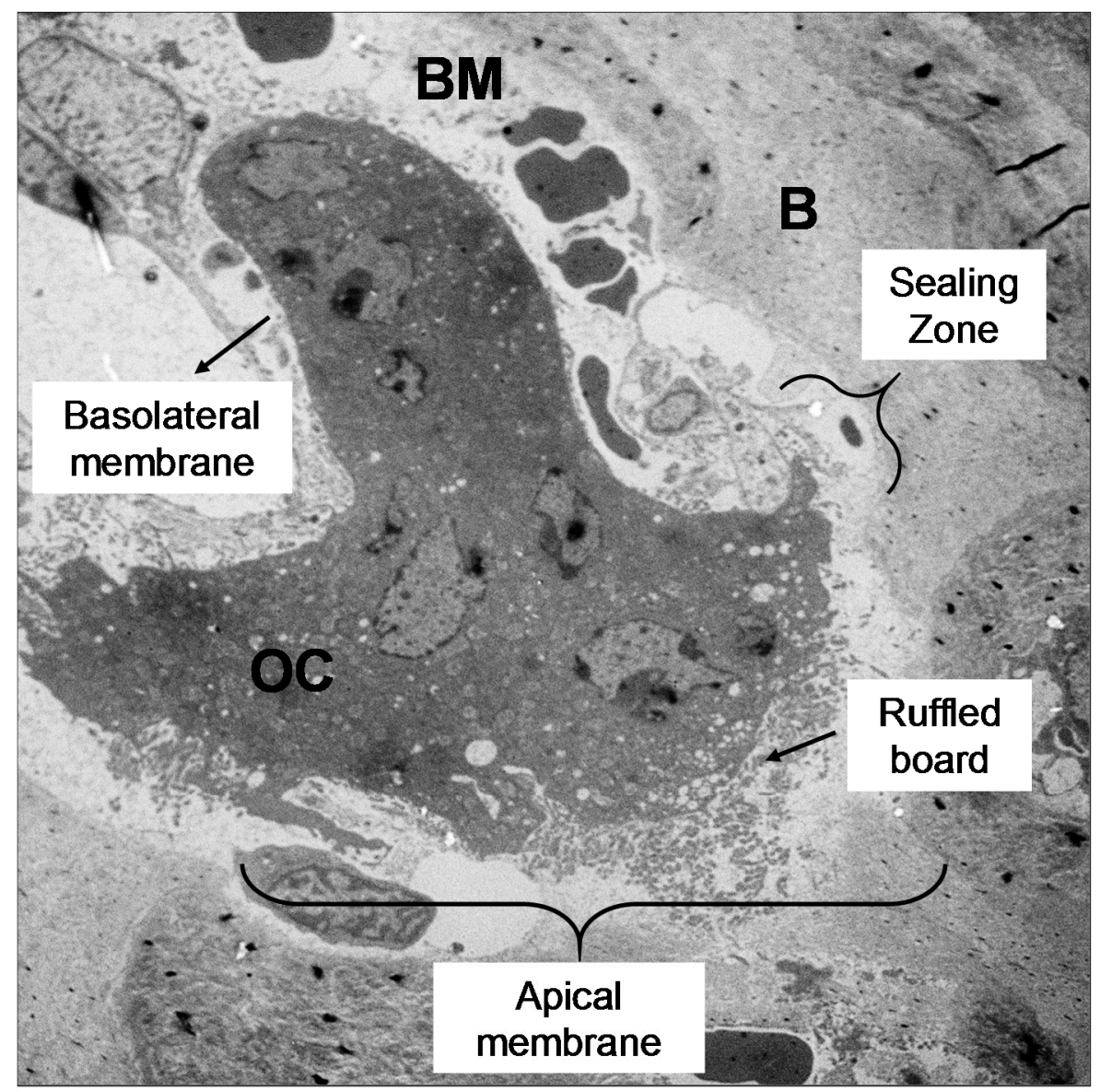

\section{0um}

Figure 3. Osteoclast morphology. Transmission electron microscopy (TEM) picture of an osteoclast from an Epon-embedded tibia from a C57/B6 mouse. Scale $10 \mu \mathrm{m}$. B: bone. OC: osteoclast. BM: bone marrow. 
Once adhered to the bone surface, the osteoclast can start the process of bone resorption. This process firstly requires the acidification of the area targeted for digestion, called the resorption lacuna or Howship lacuna, since it only becomes possible to dissolve the hydroxyapatite crystals with this chemical reaction [44]. On the intracellular side, type II carbonic anhydrase (CAII) catalyzes the hydration of carbonic anhydride $\left(\mathrm{CO}_{2}\right)$ thus forming carbonic acid $\left(\mathrm{H}_{2} \mathrm{CO}_{3}\right)$, which in turn dissociates and releases protons $\left(\mathrm{H}^{+}\right)$and carbonate ions $\left(\mathrm{HCO}_{3}{ }^{-}\right)$. The former is pumped outside the osteoclast into the Howship lacuna by the Vacuolar-ATPase (V-ATPase) proton pump inserted in the ruffled border. At the same time, the chloride ion $\left(\mathrm{Cl}^{-}\right) / \mathrm{HCO}_{3}$ exchanger allows the $\mathrm{Cl}^{-}$to enter and $\mathrm{HCO}_{3}{ }^{-}$ to leave the osteoclast. Then, the proton/chloride antiporter $\mathrm{ClC7}$ (chloride channel 7) also inserted in the ruffled border, together with its $\beta$-subunit OSTM1 (osteopetrosis-associated transmembrane protein 1), allows the release of $\mathrm{Cl}^{-}$into the Howship lacuna [16,45]. Gene mutations in any one of the members of this molecular machinery induces the osteoclast-rich osteopetrosis [46,47], characterized by a high osteoclast number, which however are unable to resorb bone.

We now have hydrochloride acid $(\mathrm{HCl})$ inside the resorption lacuna, which allows the dissolution of the inorganic matrix and the subsequent exposure of collagen fibers, which can now be digested by lysosomal enzymes, mainly acid hydrolases, released into the lacuna by the osteoclasts $[16,45]$. Cathepsin K (CstK) and Metalloproteinase 9 are crucial enzymes involved in this process [48-50].

\subsubsection{Regulation of Osteoclast Differentiation and Activity}

Together with the M-CSF and RANKL, there is a network of paracrine and systemic factors regulating osteoclast differentiation $[19,51]$. Among these, the proinflammatory cytokines play a crucial role in the enhancement of osteoclast differentiation. Indeed, TNF $\alpha$ induces osteoclast differentiation directly by activating NF- $\mathrm{KB}$ and JNK (c-Jun N-terminal kinases) in a RANKL-independent manner [52] and indirectly by stimulating the osteoblasts to express RANKL [53]. In the same way, IL-1, IL-6 and IL-11 are potent osteoclastogenic factors [54-57]. Other molecules, such as EGF (epidermal growth factor), TGF $\alpha$, OSF (osteoclast-stimulating factor), ECF-L (eosinophil chemiotactic factor-L) and Activin A increase both osteoclast differentiation and activity [54,58-60].

In contrast, in addition to OPG, cytokines such us IL-3, IL-4, IL-10 and IL-12 inhibit osteoclast differentiation and bone resorption [61-64] (Figure 4).

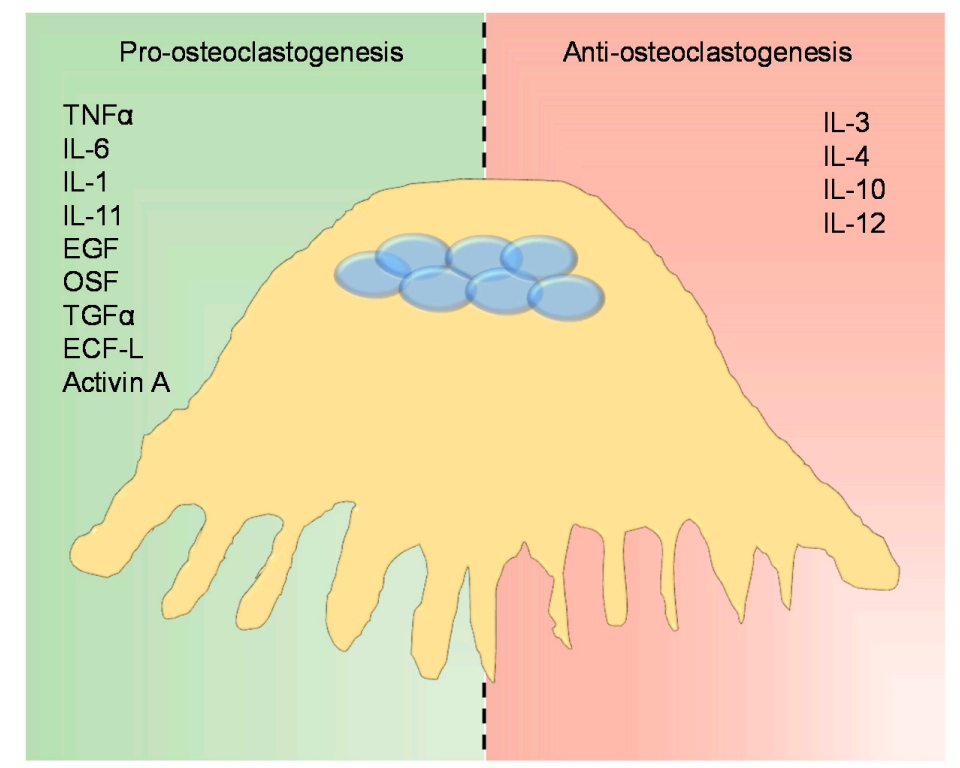

Figure 4. Osteoclast regulation. Cartoon illustrating the main molecules involved in the regulation of osteoclast differentiation with a pro- (green side) and anti- (red side) osteoclastogenic effect. 
Several hormones regulate osteoclast fate, including estrogen and testosterone, PTH, calcitonin, glucocorticoids, thyroid hormone and serotonin [51,65]. According to the topic of this review article we will focus our attention on the ability of sex hormones to regulate osteoclast activity.

Both estrogens and androgens impair osteoclast formation and survival [51,66]. Sex hormones can act through a genotropic signal, by binding their intracellular receptor and, after translocation into the nucleus, inducing the transcription of target genes. They can also act through a non-genotropic pathway mediated by plasma membrane receptors eventually leading to the stimulation of calcium flux and the activation of cytoplasmic kinases $[51,66]$.

It has been demonstrated that estrogens induce the expression of the death receptor First Apoptosis Signal (FAS)-ligand in osteoclasts, thus acting as a pro-apoptotic stimulus [67]. Indeed, the lack of ER $\alpha$ does not affect osteoclast differentiation, however it increases their lifespan [67].

\section{Alterations of Bone Remodelling: The Vicious Cycle}

As already told, any unbalance between the resorption and formation phases is responsible for an altered bone mass, eventually leading to a pathological condition. Regardless of the type of bone metastases (i.e., osteolytic vs. osteosclerotic), they are the result of a severe deregulation of the bone remodeling process, thus transforming a virtuous cycle into a vicious one (Figure 5).

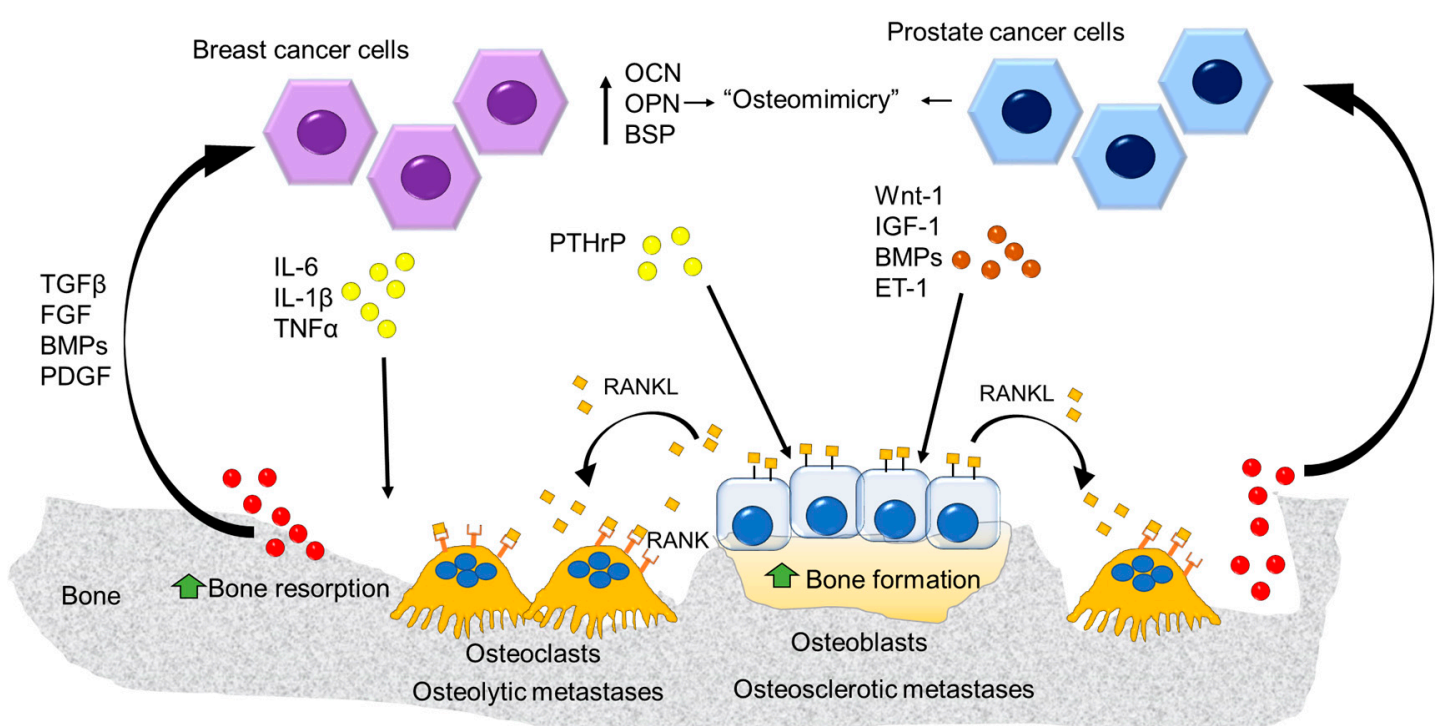

Figure 5. The "vicious" cycle. Breast cancer cells release several factors stimulating osteoclast formation and enhancing bone resorption (osteolytic metastasis). On the other side, the prostate cancer cells act on the osteoblast stimulating bone formation (osteosclerotic metastasis) along with the stimulation of the osteoblast-mediated osteoclastogenesis via RANKL expression inducing osteolytic lesions. At the same time the factors released from the bone matrix enhance the tumor growth fueling the "vicious" cycle.

The vicious cycle is the core of bone metastasis development and strictly relies on the ability of tumor cells to "subjugate" bone resident cells (i.e., osteoblasts and osteoclasts) for their own benefit. Tumor cells able to reach the bone present with specific features, enabling their survival in a hostile tissue. One of these is summarized by the phenomenon of "osteomimicry", that is the ability of tumor cells that preferentially metastasize the bone to express a genetic profile resembling that of the resident cells, thus acquiring a more favorable phenotype for survival in the bone [68]. More specifically, we refer to an osteoblast mimicry, by which both prostate and breast cancer cells produce bone matrix proteins such as osteocalcin (OCN), bone sialoprotein (BSP) and osteopontin (OPN) which are also involved in tumor invasion [69-71]. Since osteoblasts are the main paracrine regulators of osteoclasts in the bone, this function is also included in the osteomimetic properties of tumor cells [9]. In the case 
of osteolytic bone metastases (Figure 6), tumor cells produce several factors that directly or indirectly account for an exacerbated formation and activity of osteoclasts. The former include several cytokines, such as IL-6, IL-1 $\beta$ and TNF $\alpha$, all promoting the formation of an abnormal number of osteoclasts, eventually leading to an exaggerated bone erosion which would never have been balanced by a proper bone formation. Of note, these factors also act on osteoblasts by promoting their apoptosis [72]. This scenario, compatible with a condition of chronic inflammation, further highlights the role of this condition in tumor progression and metastasis.

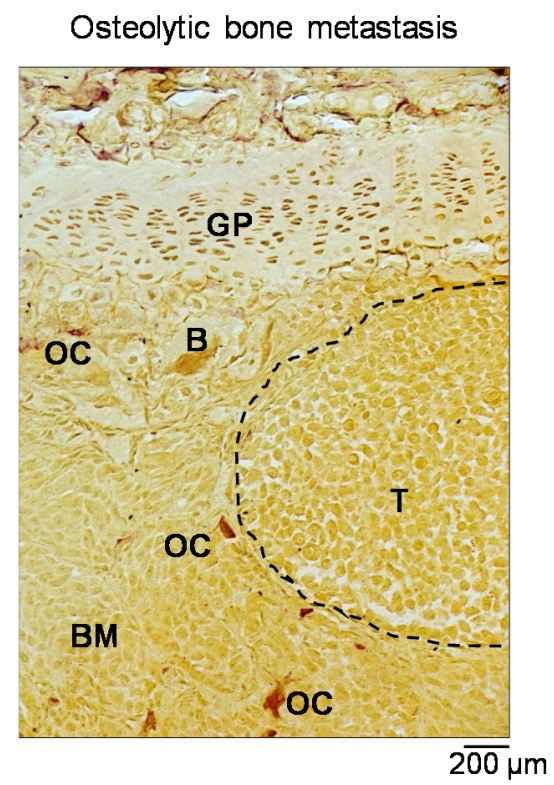

Figure 6. Osteolytic bone metastasis. Staining for the tartrate-resistant acid phosphatase (TRAcP) activity perfomed on a histological section of a tibia collected from a BALB-c nu/nu mouse intratibially injected with the human breast cancer cells MDA-MB-231. Purple cells represent the osteoclasts. Dashed line: tumor area. Scale: $200 \mu \mathrm{m}$. B: bone. OC: osteoclast. BM: bone marrow. GP: growth plate. T: tumor.

Another crucial molecule in this vicious cycle is the parathyroid hormone-related protein (PTHrP), a paracrine regulator of bone remodeling produced by osteoblasts. Tumor cells indirectly stimulate osteoclastogenesis through this molecule as it increases RANKL expression by osteoblasts [73].

The exaggerated osteoclast formation and bone destruction create the physical space in which tumor cells can grow and reach a critical mass. However, this huge destruction of bone matrix also leads to another nasty consequence which is responsible for the perpetuation of the vicious cycle: the release of previously mentioned growth factors, such as BMPs, TGF $\beta$, FGF, and platelet-derived growth factor (PDGF). In physiological condition, the factors help osteoclast-osteoblast factor coupling, whereas in this circumstance, they exert a prosurvival effect on the tumor cells.

Another detrimental effect of the vicious cycle is the release of an abnormal amount of calcium, responsible for hypercalcemia, which dramatically worsens the condition of bone metastatic patients. Likewise, a direct effect of calcium on tumor cells has also been demonstrated, as the cells can express calcium-sensing receptors, eventually leading to an increased proliferation and survival of tumor cells [74].

A similar vicious cycle is also established in osteosclerotic lesions, although in this case the prominent players are tumor-derived molecules affecting osteoblast differentiation and function [75]. Among them, wingless-related integration site (Wnt)-1, IGF-1, BMPs and endothelin (ET)-1 are the main molecules secreted by prostate cancer cells that stimulate the osteoblasts [76,77]. These factors induce the deposition of new unmineralized bone matrix (osteoid) enriched in growth factors and 
non-collagenous proteins. This fertile 'soil' attracts the prostate cancer cells, allowing them on one side to growth and survive in the bone environment, and on the other to stimulate the osteoblasts, thus enhancing the vicious cycle $[78,79]$. Paradoxically, the increased bone formation could reduce the space for the tumor cells in the bone environment, slowing down the progression of the osteosclerotic lesion. Nevertheless, simultaneously factors produced by the prostate cancer cells and the osteoblast-derived RANKL stimulate bone resorption creating the space for the tumor growth $[75,78,79]$. Once the disease enters the 'osteolytic phase' the osteoclast activity becomes prominent, thus reducing patient survival $[75,78,79]$.

Recently, new findings demonstrated that the vicious cycle in prostate cancer-induced bone metastases is a complex system. Indeed, several players including exosomes, mesenchymal stem cells, macrophages, T cells and nerves have been indicated as integrated parts of the vicious cycle in osteoblastic skeletal lesions [80].

Once again, this evidence highlights the complexity of the bone metastases and explains why their treatment represents a real challenge for the researchers in the field.

\section{The Osteoclast as Therapeutic Target}

Since the exacerbated osteoclast activity is a key point common to all bone metastases, no matter if they are osteolytic or osteosclerotic, it is conceivable to identify the osteoclast as a very useful target. Over the years, the physiology of the osteoclast has been deeply investigated; now we have quite a complete picture of the most important mechanisms underlying its formation and activity. This leads us to the identification of useful targets aimed at restraining the exacerbated bone destruction occurring in bone metastases. In line with this, several antiresorptive molecules have been identified so far, which are frequently successfully used for the treatment of post-menopausal osteoporosis.

Below we will describe the principal therapeutic arms employed so far, as well as some new promising therapeutic strategies under preclinical investigation.

\subsection{Current Antiresorptive Therapies}

\subsubsection{Bisphosphonates}

It seems unbelievable, but these compounds were synthesized for the first time at the end of the XIX century for purposes not related at all to bone health. They were used in the detergent industry (i.e., acid etidronic, or etidronate) and for the depuration of aquifer, thanks to their phosphate-carbon-phosphate (P-C-P) backbone structure, by which they efficaciously chelate calcium and some ion metals. Due to the high affinity for hydroxyapatite crystals, the use of bisphosphonate therapeutics in osteoporosis started 40 years ago, giving rise to different generations of bisphosphonates, all targeting the osteoclast, until the third-generation compound zoledronate. Once delivered to the bone, they are taken up by the osteoclasts where they induce apoptosis by different mechanisms [81]. Clodronate and etidronate belong to the non-nitrogen containing bisphosphonates, which induce osteoclast apoptosis by inhibiting the mitochondrial adenine nucleotide translocase [82]. Nitrogen containing bisphosphonates (i.e., ibandronate, pamidronate, risedronate, alendronate and zoledronate) induce osteoclast apoptosis by interfering with the mevalonate pathway, leading to the accumulation of triphosphoric acid 1-adenosin-5'-y1 ester 3-(3-methylbut-3-enyl) ester (ApppI) and of isopentenyl pyrophosphate (IPP), which in turn induce osteoclast apoptosis [83]. Moreover, the nitrogen-containing bisphosphonates inactivate osteoclasts by inhibiting the enzyme farnesyl diphosphate synthase in the cholesterol pathway, leading to a reduction of GTPase prenylation, an essential process for the cytoskeletal organization and vesicular trafficking [84].

Currently, the most effective bisphosphonate seems to be zoledronate, which significantly prevents skeletal related events and improves the quality of life [85]. Interestingly, in clinical trials in which zoledronate has been used in adjuvant and neoadjuvant therapy of early breast cancer patients, it has 
also been shown to have anticancer activity, specifically in those patients with low levels of estrogens, eventually leading to improved survival [86].

Unfortunately, bisphosphonates can have some side effects such as osteonecrosis of the jaw, bone/joint pain and atypical fractures [87]. Moreover, long term treatments can cause hypocalcemia [88]. Another pitfall of this treatments is caused by the high affinity to the bone: bisphosphates build up in this tissue and remain for a long time, causing the bone to become adynamic.

\subsubsection{Denosumab}

This is a humanized anti-RANKL antibody, which blocks osteoclast formation by inhibiting RANKL-RANK interaction. The drug reflects the physiological role of OPG; the recombinant OPG-Fc protein was first synthesized to block the RANKL/RANK pathway in preclinical studies. This compound was then discontinued for its adverse effects linked to an immune response to OPG-Fc [86].

Phase-III clinical trials demonstrated Denosumab to be more effective in delaying the onset of SREs and time to first bone metastases in prostate and breast cancer patients compared to Zoledronate, eventually leading to an increase of bone metastasis-free survival [85].

The incidence of hypocalcemia in Denosumab-treated patients is higher than with zoledronate treatment (12.4\% vs. $5.3 \%$, respectively) [88]. By contrast, zoledronate is excreted by the kidney and therefore should not be recommended to prevent SREs in patients suffering from renal failure. These patients could instead benefit from treatment with denosumab, which is not cleared by the kidney [89]. Other side effects reported are: osteonecrosis of the jaw, nausea, and fatigue [85].

\subsection{Anti Resorptive Treatment as an Adjuvant Therapy in Breast Cancer Patients}

Neoadjuvant treatment of breast cancer patients with anti-estrogen therapies, despite reducing tumor cell proliferation, is instead detrimental for bone, giving rise to a condition of osteoporosis and increased incidence of fracture. Most importantly, this condition likely creates favorable conditions for the development of osteolytic bone metastases. Therefore, it is now clear that there is an urgent need to preserve bone health in breast cancer patients. According to the recent guidelines of the European Society for Medical Oncology, breast cancer patients should be monitored for their bone mineral density. Moreover, some reports suggest that for those breast cancer patients who are at risk of cancer treatment-induced bone loss, which includes not only the aromatase inhibitors but also some chemotherapies (i.e., Doxorubicin, 5-fluorouracil), a preventive treatment with zoledronate or denosumab could be beneficial to improve survival. Indeed, there is evidence that early intervention may delay the development of bone metastases. Analysis of patients with breast cancer and bone metastases using data from two phase II clinical trials revealed that the benefit of high-dose zoledronic acid was greater in patients whose therapy was initiated before the onset of bone pain than in those who received treatment after the onset of bone pain [6]. Moreover, bone metastases were more common in women who received delayed treatment than in those who started zoledronic acid immediately [5].

\subsection{Antitumoral Effects of Antiresorptive Therapies}

Some in vitro and preclinical studies highlighted a role for zoledronate and denosumab as inhibitors of tumor growth. This is obvious for denosumab, since RANKL plays a key role in mammary gland development as well as in its tumorigenesis [90,91]. In addition, the inhibition of the effect of RANKL could enhance the antitumor immune response, thus reducing the regulatory T cells [89]. To support the role of RANKL in tumor progression, patients with low or no expression of RANK in primary lesions showed a better survival outcome [92].

With regard to bisphosphonates, recent evidence shows that zoledronate induces caspase-dependent apoptosis in renal cancer, impairs angiogenesis and reduces the migration and invasion of tumor cells [93-95]. Moreover, zoledronic acid induces modulations of the immune system increasing the sensitivity of tumor cells to the $\gamma \delta$ T cell-mediated cell lysis [95]. 
Finally, clinical data revealed that the use of bisphosphonates was correlated with a reduction in risk of developing postmenopausal breast cancer $[96,97]$ along with a reduction of breast cancer-associated mortality [98].

The inhibitory effect of bisphosphonates, particularly zoledronate, on tumor progression and dissemination may be explained at least in part by the fact that they are able to change the bone microenvironment making it less prone 'to host' and support the tumor cells [99].

\subsection{New Antiresorptive Therapeutic Strategies}

Recent studies have been focused on identifying new alternative therapies fighting the vicious cycle by targeting the osteoclasts [86], as described below.

\subsubsection{Cathepsin K Inhibitors}

Cathepsin $\mathrm{K}$ is a lysosomal cysteine protease highly expressed by osteoclasts. Following mineral matrix dissolution, cathepsin $\mathrm{K}$ degrades the collagen fibers, leading to the release of $\mathrm{N}$-telopeptides fragments [16]. In the context of bone metastasis, cathepsin $\mathrm{K}$ is expressed by osteoclasts and some metastatic breast cancer cells [100]. However, the inhibition of cathepsin $\mathrm{k}$ does not affect the tumor cell proliferation [101].

Although results of in vitro and preclinical studies aimed at inhibiting cathepsin $\mathrm{K}$ activity were promising, all clinical trials for cathepsin $\mathrm{K}$ inhibitors have been discontinued. In particular, the basic lysosomotropic cathepsin K inhibitor Balicatib (clinical phase II; NCT00371670) was able to reduce bone resorption increasing the BMD in patients with osteoarthritis. Nevertheless, its clinical development has been discontinued due to its side effects on skin, caused by a prolonged lysosomal trapping of the inhibitor [102].

Another promising cathepsin $\mathrm{K}$ inhibitor was Odanacatib. Indeed, pre-clinical and clinical studies showed that it was effective in treating both osteoporosis and cancer-associated bone metastases with the same efficacy as zoledronate [103]. Unfortunately, Odanacatib was also discontinued in phase III clinical trials due to an increased risk of atrial fibrillation and stroke.

\subsection{2. c-src Inhibitors}

As already mentioned, the proto-oncogene c-src plays a relevant role in bone metabolism. In fact, c-src knock out mice present with an osteopetrotic phenotype due to failure of src-mutant osteoclasts to form the ruffled border [33], while decreased c-src expression enhances osteoblast differentiation and bone formation [104]. Due to its oncogenic nature, c-src also stimulates cancer cell proliferation and tumorigenesis [105-107]. All these data make c-src the perfect target to block the vicious cycle.

There are several c-src inhibitors that have been developed so far, such as Dasatinib, Bosutinib, Ponatinib and Vandetanib, which are FDA-approved for different diseases. Preclinical studies carried out on metastatic prostate cancer cells showed that the c-src inhibitors Bosutinib and Saracatinib affect tumor cell proliferation and reduce cancer-induced osteolysis by inhibiting the phosphorylation of AKT, MAPK and FAK $[108,109]$. Moreover, Maroni et al. [110] showed that treatment with the c-src inhibitor Dasatinib increased the survival of mice xenotransplanted with the human bone metastatic 1833 cells, by the inhibition of cell autophagy.

To date there are ongoing phase I/II clinical trials for the use of Dasatinib and Saracatinib to treat bone metastasis that are promising in terms of reduction of disease progression [86].

\subsubsection{Inhibitors of Integrins}

As already discussed in this review, integrins, and in particular $\alpha v \beta 3$ integrin, play a central role in osteoclast biology and bone resorption. Overexpression of the $\alpha v \beta 3$ integrin in tumor cells is also essential for their bone homing [111].

In vitro studies demonstrated that the anti- $\alpha \mathrm{v} \beta 3$ integrin antibody was able to reduce bone resorption, impairing osteoclast adhesion to the bone surface [112]. In line with this, the use of 
PSK1404, an antagonist of the $\alpha \mathrm{v} \beta 3$ integrin, in an in vivo model of breast cancer, reduced bone resorption by decreasing the secretion of pro-osteoclast activity tumor factors [113].

So far, there is an ongoing phase II clinical trial for the treatment of metastatic prostate cancer patients using the anti- $\alpha \mathrm{v} \beta 3$ integrin human monoclonal antibody, Etaracizumab, in combination with docetaxel, zoledronate and prednisone (NCT00072930). Unfortunately, the results of the trial are not yet public.

\section{Anabolic Treatments}

\section{Antisclerostin Antibodies}

Sclerostin (SOST) is a protein, mainly produced by the osteocytes in bone, that binds LRP5/6 (low-density lipoprotein receptor-related protein 5 and 6) inhibiting the Wnt signaling pathways, which in turn plays a crucial role in osteoblast differentiation [114]. The inhibition of SOST has an osteoanabolic effect, inducing an increase in bone formation [115]. Interestingly, SOST is also produced by some tumor cells, including breast cancer cells, and its serum level is increased in some breast cancer patients [116,117]. Romosozumab, Blosozumab and BPS804 are human monoclonal antibodies against SOST in clinical development for the treatment of bone diseases such as osteoporosis and osteogenesis imperfecta $[118,119]$. Moreover, in vivo experiments performed with animal models of multiple myeloma treated with an anti-SOST antibody revealed the efficacy of this treatment in increasing bone mass and preventing tumor-associated bone loss [120]. Based on this available information, the use of anti-SOST antibodies for the treatment of bone metastasis could be taken into account.

\section{Conclusions}

For breast and prostate cancer patients, bone is the preferential site of metastases, which offers a better chance of survival compared to metastases in soft tissues. This encourages researchers in the field to identify new effective therapies to prolong life expectancy and quality of life for patients. Other strategical therapeutic options to be considered are those able to preserve bone health, a noteworthy aspect in breast and prostate cancer patients if we consider that they are treated with therapies known to inhibit sexual hormones. This is the right method to kill breast and prostate cancer cells however also having a detrimental effect on bone, thus inducing a waste in bone mass. The latter condition could create a good environment for the onset of bone metastases, therefore preserving the correct bone mass in breast and prostate cancer patients could pose an advantage, eventually preventing or delaying the occurrence of the first bone metastasis as well as the skeletal related events. A promising option could be to employ the antiresorptive treatments as early as possible in order to prevent bone loss caused by the neoadjuvant therapy.

Funding: This research was funded by "Associazione Italiana per la Ricerca sul Cancro" grant number [IG 2015 Id. 16826] to N.R.

Acknowledgments: We are grateful to Annabel Curle for her invaluable contribution in the editing of the manuscript.

Conflicts of Interest: The authors declare no conflict of interest and the founding sponsors had no role in the design of the study; in the collection, analyses, or interpretation of data; in the writing of the manuscript, and in the decision to publish the results.

\section{References}

1. Coleman, R.E. Metastatic bone disease: Clinical features, pathophysiology and treatment strategies. Cancer Treat. Rev. 2001, 27, 165-176. [CrossRef] [PubMed]

2. Coleman, R.E.; Smith, P.; Rubens, R.D. Clinical course and prognostic factors following bone recurrence from breast cancer. Br. J. Cancer 1998, 77, 336-340. [CrossRef] [PubMed]

3. Robson, M.; Dawson, N. How is androgen-dependent metastatic prostate cancer best treated? Hematol. Oncol. Clin. N. Am. 1996, 10, 727-747. [CrossRef] 
4. Koizumi, M.; Yoshimoto, M.; Kasumi, F.; Ogata, E. Comparison between solitary and multiple skeletal metastatic lesions of breast cancer patients. Ann. Oncol. 2003, 14, 1234-1240. [CrossRef] [PubMed]

5. Coleman, R.; De Boer, R.; Eidtmann, H.; Llombart, A.; Davidson, N.; Neven, P.; Von Minckwitz, G.; Sleeboom, H.P.; Forbes, J.; Barrios, C.; et al. Zoledronic acid (zoledronate) for postmenopausal women with early breast cancer receiving adjuvant letrozole (ZO-FAST study): Final 60-month results. Ann. Oncol. 2013, 24, 398-405. [CrossRef] [PubMed]

6. Costa, L.; Lipton, A.; Hadji, P.; Chen, Y.M.; Kosmidis, P. Treatment of bone metastases before the onset of pain. Int. J. Clin. Oncol. 2013, 18, 531-538. [CrossRef] [PubMed]

7. Selvaggi, G.; Scagliotti, G.V. Management of bone metastases in cancer: A review. Crit. Rev. Oncol. Hematol. 2005, 56, 365-378. [CrossRef] [PubMed]

8. Clohisy, D.R.; Mantyh, P.W. Bone cancer pain. Cancer 2003, 97, 866-873. [CrossRef] [PubMed]

9. Roodman, G.D. Mechanisms of Bone Metastasis. N. Engl. J. Med. 2004, 350, 1655-1664. [CrossRef] [PubMed]

10. Paget, S. The distribution of secondary growth in cancer of the breast. Lancet 1889, 133, 571-573. [CrossRef]

11. Kenkre, J.S.; Bassett, J.H. The Bone Remodelling Cycle. Ann. Clin. Biochem. 2018, 55, 308-327. [CrossRef] [PubMed]

12. Hauge, E.M.; Qvesel, D.; Eriksen, E.F.; Mosekilde, L.; Melsen, F. Cancellous bone remodeling occurs in specialized compartments lined by cells expressing osteoblastic markers. J. Bone Miner. Res. 2001, 16, 1575-1582. [CrossRef] [PubMed]

13. Everts, V.; Delaissié, J.M.; Korper, W.; Jansen, D.C.; Tigchelaar-Gutter, W.; Saftig, P.; Beertsen, W. The bone lining cell: Its role in cleaning Howship's lacunae and initiating bone formation. J. Bone Miner. Res. 2002, 17, 77-90. [CrossRef] [PubMed]

14. Delaisse, J.-M. The reversal phase of the bone-remodeling cycle: Cellular prerequisites for coupling resorption and formation. Bonekey Rep. 2014, 3. [CrossRef] [PubMed]

15. Anderson, H.C.; Garimella, R.; Tague, S.E. The role of matrix vesicles in growth plate development and biomineralization. Front. Biosci. 2005, 10, 822-837. [CrossRef] [PubMed]

16. Cappariello, A.; Maurizi, A.; Veeriah, V.; Teti, A. Reprint of: The Great Beauty of the osteoclast. Arch. Biochem. Biophys. 2014, 561, 13-21. [CrossRef] [PubMed]

17. Sherr, C.J. Colony-stimulating factor-1 receptor. Blood 1990, 75, 1-12. [PubMed]

18. Wiktor-Jedrzejczak, W.; Bartocci, A.; Ferrante, A.W.; Ahmed-Ansari, A.; Sell, K.W.; Pollard, J.W.; Stanley, E.R. Total absence of colony-stimulating factor 1 in the macrophage-deficient osteopetrotic (OP/OP) mouse. Proc. Natl. Acad. Sci. USA 1990, 87, 4828-4832. [CrossRef] [PubMed]

19. Soysa, N.S.; Alles, N.; Aoki, K.; Ohya, K. Osteoclast formation and differentiation: An overview. J. Med. Dent. Sci. 2012, 59, 65-74. [CrossRef] [PubMed]

20. Lacey, D.L.; Timms, E.; Tan, H.L.; Kelley, M.J.; Dunstan, C.R.; Burgess, T.; Elliott, R.; Colombero, A.; Elliott, G.; Scully, S.; et al. Osteoprotegerin ligand is a cytokine that regulates osteoclast differentiation and activation. Cell 1998, 93, 165-176. [CrossRef]

21. Yasuda, H.; Shima, N.; Nakagawa, N.; Yamaguchi, K.; Kinosaki, M.; Mochizuki, S.; Tomoyasu, A.; Yano, K.; Goto, M.; Murakami, A.; et al. Osteoclast differentiation factor is a ligand for osteoprotegerin/ osteoclastogenesis-inhibitory factor and is identical to TRANCE/RANKL. Proc. Natl. Acad. Sci. USA 1998, 95, 3597-3602. [CrossRef] [PubMed]

22. Nakashima, T.; Takayanagi, H. New regulation mechanisms of osteoclast differentiation. Ann. N. Y. Acad. Sci. 2011, 1240. [CrossRef] [PubMed]

23. Simonet, W.; Lacey, D.; Dunstan, C.; Kelley, M.; Chang, M.-S.; Lüthy, R.; Nguyen, H.; Wooden, S.; Bennett, L.; Boone, T.; et al. Osteoprotegerin: A Novel Secreted Protein Involved in the Regulation of Bone Density. Cell 1997, 89, 309-319. [CrossRef]

24. Kong, Y.Y.; Yoshida, H.; Sarosi, I.; Tan, H.L.; Timms, E.; Capparelli, C.; Morony, S.; Oliveira-dos-Santos, A.J.; Van, G.; Itie, A.; et al. OPGL is a key regulator of osteoclastogenesis, lymphocyte development and lymph-node organogenesis. Nature 1999, 397, 315-323. [CrossRef] [PubMed]

25. Dougall, W.C.; Glaccum, M.; Charrier, K.; Rohrbach, K.; Brasel, K.; De Smedt, T.; Daro, E.; Smith, J.; Tometsko, M.E.; Maliszewski, C.R.; et al. RANK is essential for osteoclast and lymph node development. Genes Dev. 1999, 13, 2412-2424. [CrossRef] [PubMed] 
26. Li, J.; Sarosi, I.; Yan, X.Q.; Morony, S.; Capparelli, C.; Tan, H.L.; McCabe, S.; Elliott, R.; Scully, S.; Van, G.; et al. RANK is the intrinsic hematopoietic cell surface receptor that controls osteoclastogenesis and regulation of bone mass and calcium metabolism. Proc. Natl. Acad. Sci. USA 2000, 97, 1566-1571. [CrossRef] [PubMed]

27. Bucay, N.; Sarosi, I.; Dunstan, C.R.; Morony, S.; Tarpley, J.; Capparelli, C.; Scully, S.; Tan, H.L.; Xu, W.; Lacey, D.L.; et al. Osteoprotegerin-deficient mice develop early onset osteoporosis and arterial calcification. Genes Dev. 1998, 12, 1260-1268. [CrossRef] [PubMed]

28. Asagiri, M.; Sato, K.; Usami, T.; Ochi, S.; Nishina, H.; Yoshida, H.; Morita, I.; Wagner, E.F.; Mak, T.W.; Serfling, E.; et al. Autoamplification of NFATc1 expression determines its essential role in bone homeostasis. J. Exp. Med. 2005, 202, 1261-1269. [CrossRef] [PubMed]

29. Takayanagi, H.; Kim, S.; Koga, T.; Nishina, H.; Isshiki, M.; Yoshida, H.; Saiura, A.; Isobe, M.; Yokochi, T.; Inoue, J.I.; et al. Induction and activation of the transcription factor NFATc1 (NFAT2) integrate RANKL signaling in terminal differentiation of osteoclasts. Dev. Cell 2002, 3, 889-901. [CrossRef]

30. Matsumoto, M.; Kogawa, M.; Wada, S.; Takayanagi, H.; Tsujimoto, M.; Katayama, S.; Hisatake, K.; Nogi, Y. Essential role of p38 mitogen-activated protein kinase in cathepsin $\mathrm{K}$ gene expression during osteoclastogenesis through association of NFATc1 and PU.1. J. Biol. Chem. 2004, 279, 45969-45979. [CrossRef] [PubMed]

31. Kim, K.; Kim, J.H.; Lee, J.; Jin, H.-M.; Lee, S.-H.; Fisher, D.E.; Kook, H.; Kim, K.K.; Choi, Y.; Kim, N. Nuclear factor of activated $\mathrm{T}$ cells $\mathrm{c} 1$ induces osteoclast-associated receptor gene expression during tumor necrosis factor-related activation-induced cytokine-mediated osteoclastogenesis. J. Biol. Chem. 2005, 280, 35209-35216. [CrossRef] [PubMed]

32. Crotti, T.N.; Flannery, M.; Walsh, N.C.; Fleming, J.D.; Goldring, S.R.; McHugh, K.P. NFATc1 regulation of the human $\beta 3$ integrin promoter in osteoclast differentiation. Gene 2006, 372, 92-102. [CrossRef] [PubMed]

33. Mbalaviele, G.; Chen, H.; Boyce, B.F.; Mundy, G.R.; Yoneda, T. The role of cadherin in the generation of multinucleated osteoclasts from mononuclear precursors in murine marrow. J. Clin. Investig. 1995, 95, 2757-2765. [CrossRef] [PubMed]

34. Vignery, A. Osteoclasts and giant cells: Macrophage-macrophage fusion mechanism. Int. J. Exp. Pathol. 2000, 81, 291-304. [CrossRef] [PubMed]

35. Verrier, S.; Hogan, A.; McKie, N.; Horton, M. ADAM gene expression and regulation during human osteoclast formation. Bone 2004, 35, 34-46. [CrossRef] [PubMed]

36. Yagi, M.; Miyamoto, T.; Sawatani, Y.; Iwamoto, K.; Hosogane, N.; Fujita, N.; Morita, K.; Ninomiya, K.; Suzuki, T.; Miyamoto, K.; et al. DC-STAMP is essential for cell-cell fusion in osteoclasts and foreign body giant cells. J. Exp. Med. 2005, 202, 345-351. [CrossRef] [PubMed]

37. Lee, S.H.; Rho, J.; Jeong, D.; Sul, J.Y.; Kim, T.; Kim, N.; Kang, J.S.; Miyamoto, T.; Suda, T.; Lee, S.K.; et al. V-ATPase V0subunit d2-deficient mice exhibit impaired osteoclast fusion and increased bone formation. Nat. Med. 2006, 12, 1403-1409. [CrossRef] [PubMed]

38. Marchisio, P.C.; Cirillo, D.; Naldini, L.; Primavera, M.V.; Teti, A.; Zambonin-Zallone, A. Cell-substratum interaction of cultured avian osteoclasts is mediated by specific adhesion structures. J. Cell Biol. 1984, 99, 1696-1705. [CrossRef] [PubMed]

39. Schachtner, H.; Calaminus, S.D.J.; Thomas, S.G.; Machesky, L.M. Podosomes in adhesion, migration, mechanosensing and matrix remodeling. Cytoskeleton 2013, 70, 572-589. [CrossRef] [PubMed]

40. Schlesinger, P.H.; Blair, H.C.; Teitelbaum, S.L.; Edwards, J.C. Characterization of the osteoclast ruffled border chloride channel and its role in bone resorption. J. Biol. Chem. 1997, 272, 18636-18643. [CrossRef] [PubMed]

41. Baron, R. Polarity and membrane transport in osteoclasts. Connect. Tissue Res. 1989, 20, 109-120. [CrossRef] [PubMed]

42. Mulari, M.; Vääräniemi, J.; Väänänen, H.K. Intracellular membrane trafficking in bone resorbing osteoclasts. Microsc. Res. Tech. 2003, 61, 496-503. [CrossRef] [PubMed]

43. Hirvonen, M.J.; Fagerlund, K.; Lakkakorpi, P.; Väänänen, H.K.; Mulari, M.T.K. Novel perspectives on the transcytotic route in osteoclasts. Bonekey Rep. 2013, 2. [CrossRef] [PubMed]

44. Blair, H.C.; Kahn, A.J.; Crouch, E.C.; Jeffrey, J.J.; Teitelbaum, S.L. Isolated osteoclasts resorb the organic and inorganic components of bone. J. Cell Biol. 1986, 102, 1164-1172. [CrossRef] [PubMed]

45. Baron, R. Molecular mechanisms of bone resorption by the osteoclast. Anat. Rec. 1989, 224, 317-324. [CrossRef] [PubMed] 
46. Sobacchi, C.; Schulz, A.; Coxon, F.P.; Villa, A.; Helfrich, M.H. Osteopetrosis: Genetics, treatment and new insights into osteoclast function. Nat. Rev. Endocrinol. 2013, 9, 522-536. [CrossRef] [PubMed]

47. Villa, A.; Guerrini, M.M.; Cassani, B.; Pangrazio, A.; Sobacchi, C. Infantile malignant, autosomal recessive osteopetrosis: The rich and the poor. Calcif. Tissue Int. 2009, 84, 1-12. [CrossRef] [PubMed]

48. Okada, Y.; Naka, K.; Kawamura, K.; Matsumoto, T.; Nakanishi, I.; Fujimoto, N.; Sato, H.; Seiki, M. Localization of matrix metalloproteinase 9 (92-kilodalton gelatinase/type IV collagenase = gelatinase B) in osteoclasts: Implications for bone resorption. Lab. Investig. 1995, 72, 311-322. [PubMed]

49. Zaidi, M.; Troen, B.; Moonga, B.S.; Abe, E. Cathepsin K, osteoclastic resorption, and osteoporosis therapy. J. Bone Miner. Res. 2001, 16, 1747-1749. [CrossRef] [PubMed]

50. Colnot, C. Altered fracture repair in the absence of MMP9. Development 2003, 130, 4123-4133. [CrossRef] [PubMed]

51. Del Fattore, A.; Teti, A.; Rucci, N. Osteoclast receptors and signaling. Arch. Biochem. Biophys. 2008, 473, 147-160. [CrossRef] [PubMed]

52. Kobayashi, K.; Takahashi, N.; Jimi, E.; Udagawa, N.; Takami, M.; Kotake, S.; Nakagawa, N.; Kinosaki, M.; Yamaguchi, K.; Shima, N.; et al. Tumor Necrosis Factor $\alpha$ Stimulates Osteoclast Differentiation by a Mechanism Independent of the ODF/RANKL-RANK Interaction. J. Exp. Med. 2000, 191, 275-285. [CrossRef] [PubMed]

53. Lam, J.; Takeshita, S.; Barker, J.E.; Kanagawa, O.; Ross, F.P.; Teitelbaum, S.L. TNF- $\alpha$ induces osteoclastogenesis by direct stimulation of macrophages exposed to permissive levels of RANK ligand. J. Clin. Investig. 2000, 106, 1481-1488. [CrossRef] [PubMed]

54. Palmqvist, P.; Persson, E.; Conaway, H.H.; Lerner, U.H. IL-6, leukemia inhibitory factor, and oncostatin $\mathrm{M}$ stimulate bone resorption and regulate the expression of receptor activator of NF-kappa B ligand, osteoprotegerin, and receptor activator of NF-kappa B in mouse calvariae. J. Immunol. 2002, 169, 3353-3362. [CrossRef] [PubMed]

55. Kudo, O.; Sabokbar, A.; Pocock, A.; Itonaga, I.; Fujikawa, Y.; Athanasou, N.A. Interleukin-6 and interleukin-11 support human osteoclast formation by a RANKL-independent mechanism. Bone 2003, 32, 1-7. [CrossRef]

56. Cronstein, B.N. Interleukin- 6 a key mediator of systemic and local symptoms in rheumatoid arthritis. Bull. NYU Hosp. Jt. Dis. 2007, 65 (Suppl. 1), S11-S15. [PubMed]

57. Yao, Z.; Xing, L.; Qin, C.; Schwarz, E.M.; Boyce, B.F. Osteoclast precursor interaction with bone matrix induces osteoclast formation directly by an interleukin-1-mediated autocrine mechanism. J. Biol. Chem. 2008, 283, 9917-9924. [CrossRef] [PubMed]

58. Takahashi, N.; MacDonald, B.R.; Hon, J.; Winkler, M.E.; Derynck, R.; Mundy, G.R.; Roodman, G.D. Recombinant human transforming growth factor- $\alpha$ stimulates the formation of osteoclast-like cells in long-term human marrow cultures. J. Clin. Investig. 1986, 78, 894-898. [CrossRef] [PubMed]

59. Fuller, K.; Bayley, K.E.; Chambers, T.J. Activin A is an essential cofactor for osteoclast induction. Biochem. Biophys. Res. Commun. 2000, 268, 2-7. [CrossRef] [PubMed]

60. Kurihara, N.; Menaa, C.; Maeda, H.; Haile, D.J.; Reddy, S.V. Osteoclast-stimulating Factor Interacts with the Spinal Muscular Atrophy Gene Product to Stimulate Osteoclast Formation. J. Biol. Chem. 2001, 276, 41035-41039. [CrossRef] [PubMed]

61. Owens, J.M.; Gallagher, A.C.; Chambers, T.J. IL-10 modulates formation of osteoclasts in murine hemopoietic cultures. J. Immunol. 1996, 157, 936-940. [PubMed]

62. Horwood, N.J.; Elliott, J.; Martin, T.J.; Gillespie, M.T. IL-12 alone and in synergy with IL-18 inhibits osteoclast formation in vitro. J. Immunol. 2001, 166, 4915-4921. [CrossRef] [PubMed]

63. Bendixen, A.C.; Shevde, N.K.; Dienger, K.M.; Willson, T.M.; Funk, C.D.; Pike, J.W. IL-4 inhibits osteoclast formation through a direct action on osteoclast precursors via peroxisome proliferator-activated receptor 1. Proc. Natl. Acad. Sci. USA 2001, 98, 2443-2448. [CrossRef] [PubMed]

64. Khapli, S.M.; Mangashetti, L.S.; Yogesha, S.D.; Wani, M.R. IL-3 acts directly on osteoclast precursors and irreversibly inhibits receptor activator of NF- $\mathrm{kB}$ ligand-induced osteoclast differentiation by diverting the cells to macrophage lineage. J. Immunol. 2003, 171, 142-151. [CrossRef] [PubMed]

65. Siddiqui, J.A.; Partridge, N.C. Physiological bone remodeling: Systemic regulation and growth factor involvement. Physiology 2016, 31, 233-245. [CrossRef] [PubMed]

66. Manolagas, S.C.; O'Brien, C.A.; Almeida, M. The role of estrogen and androgen receptors in bone health and disease. Nat. Rev. Endocrinol. 2013, 9, 699-712. [CrossRef] [PubMed] 
67. Nakamura, T.; Imai, Y.; Matsumoto, T.; Sato, S.; Takeuchi, K.; Igarashi, K.; Harada, Y.; Azuma, Y.; Krust, A.; Yamamoto, Y.; et al. Estrogen prevents bone loss via estrogen receptor $\alpha$ and induction of Fas ligand in osteoclasts. Cell 2007, 130, 811-823. [CrossRef] [PubMed]

68. Rucci, N.; Teti, A. Osteomimicry: How the Seed Grows in the Soil. Calcif. Tissue Int. 2018, 102, 131-140. [CrossRef] [PubMed]

69. Curatolo, C.; Ludovico, G.M.; Correale, M.; Pagliarulo, A.; Abbate, I.; Cirrillo Marucco, E.; Barletta, A. Advanced prostate cancer follow-up with prostate-specific antigen, prostatic acid phosphatase, osteocalcin and bone isoenzyme of alkaline phosphatase. Eur. Urol. 1992, 21 (Suppl. 1), 105-107. [CrossRef] [PubMed]

70. Koeneman, K.S.; Yeung, F.; Chung, L.W.K. Osteomimetic properties of prostate cancer cells: A hypothesis supporting the predilection of prostate cancer metastasis and growth in the bone environment. Prostate 1999, 39, 246-261. [CrossRef]

71. Bellahcène, A.; Bachelier, R.; Detry, C.; Lidereau, R.; Clézardin, P.; Castronovo, V. Transcriptome analysis reveals an osteoblast-like phenotype for human osteotropic breast cancer cells. Breast Cancer Res. Treat. 2007, 101, 135-148. [CrossRef] [PubMed]

72. Tsuboi, M.; Kawakami, A.; Nakashima, T.; Matsuoka, N.; Urayama, S.; Kawabe, Y.; Fujiyama, K.; Kiriyama, T.; Aoyagi, T.; Maeda, K.; et al. Tumor necrosis factor- $\alpha$ and interleukin-1 $\beta$ increase the Fas-mediated apoptosis of human osteoblasts. J. Lab. Clin. Med. 1999, 134, 222-231. [CrossRef]

73. Guise, T.A.; Yin, J.J.; Taylor, S.D.; Kumagai, Y.; Dallas, M.; Boyce, B.F.; Yoneda, T.; Mundy, G.R. Evidence for a causal role of parathyroid hormone-related protein in the pathogenesis of human breast cancer-mediated osteolysis. J. Clin. Investig. 1996, 98, 1544-1549. [CrossRef] [PubMed]

74. Kim, W.; Takyar, F.M.; Swan, K.; Jeong, J.; Vanhouten, J.; Sullivan, C.; Dann, P.; Yu, H.; Fiaschi-Taesch, N.; Chang, W.; et al. Calcium-sensing receptor promotes breast cancer by stimulating intracrine actions of parathyroid hormone-related protein. Cancer Res. 2016, 76, 5348-5360. [CrossRef] [PubMed]

75. Ibrahim, T.; Flamini, E.; Mercatali, L.; Sacanna, E.; Serra, P.; Amadori, D. Pathogenesis of osteoblastic bone metastases from prostate cancer. Cancer 2010, 116, 1406-1418. [CrossRef] [PubMed]

76. Guise, T.A.; Mohammad, K.S.; Clines, G.; Stebbins, E.G.; Wong, D.H.; Higgins, L.S.; Vessella, R.; Corey, E.; Padalecki, S.; Suva, L.; et al. Basic mechanisms responsible for osteolytic and osteoblastic bone metastases. Clin. Cancer Res. 2006, 12. [CrossRef] [PubMed]

77. Clines, G.; Mohammad, K.S.; Bao, Y.; Stephens, O.W.; Suva, L.J.; Shaughnessy, J.D.; Fox, J.W.; Chirgwin, J.M.; Guise, T. A Dickkopf homolog 1 mediates endothelin-1-stimulated new bone formation. Mol. Endocrinol. 2007, 21, 486-498. [CrossRef] [PubMed]

78. Reddi, H.; Roodman, D.; Freeman, C.; Mohla, S. Mechanisms of tumor metastasis to the bone: Challenges and opportunities. J. Bone Miner. Res. 2003, 18, 190-194. [CrossRef] [PubMed]

79. Ye, L.; Kynaston, H.G.; Jiang, W.G. Bone metastasis in prostate cancer: Molecular and cellular mechanisms (Review). Int. J. Mol. Med. 2007, 20, 103-111. [CrossRef] [PubMed]

80. Cook, L.M.; Shay, G.; Aruajo, A.; Lynch, C.C. Integrating new discoveries into the "vicious cycle" paradigm of prostate to bone metastases. Cancer Metastasis Rev. 2014, 33, 511-525. [CrossRef] [PubMed]

81. Rogers, M.J.; Crockett, J.C.; Coxon, F.P.; Mönkkönen, J. Biochemical and molecular mechanisms of action of bisphosphonates. Bone 2011, 49, 34-41. [CrossRef] [PubMed]

82. Coxon, F.P.; Thompson, K.; Rogers, M.J. Recent advances in understanding the mechanism of action of bisphosphonates. Curr. Opin. Pharmacol. 2006, 6, 307-312. [CrossRef] [PubMed]

83. Mönkkönen, H.; Auriola, S.; Lehenkari, P.; Kellinsalmi, M.; Hassinen, I.E.; Vepsäläinen, J.; Mönkkönen, J. A new endogenous ATP analog (ApppI) inhibits the mitochondrial adenine nucleotide translocase (ANT) and is responsible for the apoptosis induced by nitrogen-containing bisphosphonates. Br. J. Pharmacol. 2006, 147, 437-445. [CrossRef] [PubMed]

84. Rodan, G.A.; Reszka, A.A. Bisphosphonate mechanism of action. Curr. Mol. Med. 2002, 2, 571-577. [CrossRef] [PubMed]

85. Rosen, L.S.; Gordon, D.; Tchekmedyian, S.; Yanagihara, R.; Hirsh, V.; Krzakowski, M.; Pawlicki, M.; de Souza, P.; Zheng, M.; Urbanowitz, G.; et al. Zoledronic acid versus placebo in the treatment of skeletal metastases in patients with lung cancer and other solid tumors: A phase III, double-blind, randomized trial-the Zoledronic Acid Lung Cancer and Other Solid Tumors Study Group. J. Clin. Oncol. 2003, 21, 3150-3157. [CrossRef] [PubMed] 
86. Sousa, S.; Clézardin, P. Bone-Targeted Therapies in Cancer-Induced Bone Disease. Calcif. Tissue Int. 2018, 102, 227-250. [CrossRef] [PubMed]

87. Reyes, C.; Hitz, M.; Prieto-Alhambra, D.; Abrahamsen, B. Risks and Benefits of Bisphosphonate Therapies. J. Cell. Biochem. 2016, 117, 20-28. [CrossRef] [PubMed]

88. Body, J.J.; Bone, H.G.; de Boer, R.H.; Stopeck, A.; Van Poznak, C.; Damião, R.; Fizazi, K.; Henry, D.H.; Ibrahim, T.; Lipton, A.; et al. Hypocalcaemia in patients with metastatic bone disease treated with denosumab. Eur. J. Cancer 2015, 51, 1812-1821. [CrossRef] [PubMed]

89. Lüftner, D.; Niepel, D.; Steger, G.G. Therapeutic approaches for protecting bone health in patients with breast cancer. Breast 2018, 37, 28-35. [CrossRef] [PubMed]

90. Gonzalez-Suarez, E.; Jacob, A.P.; Jones, J.; Miller, R.; Roudier-Meyer, M.P.; Erwert, R.; Pinkas, J.; Branstetter, D.; Dougall, W.C. RANK ligand mediates progestin-induced mammary epithelial proliferation and carcinogenesis. Nature 2010, 468, 103-107. [CrossRef] [PubMed]

91. Schramek, D.; Leibbrandt, A.; Sigl, V.; Kenner, L.; Pospisilik, J.A.; Lee, H.J.; Hanada, R.; Joshi, P.A.; Aliprantis, A.; Glimcher, L.; et al. Osteoclast differentiation factor RANKL controls development of progestin-driven mammary cancer. Nature 2010, 468, 98-102. [CrossRef] [PubMed]

92. Pfitzner, B.M.; Branstetter, D.; Loibl, S.; Denkert, C.; Lederer, B.; Schmitt, W.D.; Dombrowski, F.; Werner, M.; Rüdiger, T.; Dougall, W.C.; et al. RANK expression as a prognostic and predictive marker in breast cancer. Breast Cancer Res. Treat. 2014, 145, 307-315. [CrossRef] [PubMed]

93. Ullen, A.; Schwarz, S.; Lennartsson, L.; Kalkner, K.-M.; Sandstrom, P.; Costa, F.; Lennernas, B.; Linder, S.; Nilsson, S. Zoledronic acid induces caspase-dependent apoptosis in renal cancer cell lines. Scand. J. Urol. Nephrol. 2009, 43, 98-103. [CrossRef] [PubMed]

94. Tang, X.; Zhang, Q.; Shi, S.; Yen, Y.; Li, X.; Zhang, Y.; Zhou, K.; Le, A.D. Bisphosphonates suppress insulin-like growth factor 1-induced angiogenesis via the HIF-1 $\alpha$ /VEGF signaling pathways in human breast cancer cells. Int. J. Cancer 2010, 126, 90-103. [CrossRef] [PubMed]

95. Zekria, J.; Mansour, M.; Karim, S.M. The anti-tumour effects of zoledronic acid. J. Bone Oncol. 2014, 3, $25-35$. [CrossRef] [PubMed]

96. Prentice, R.L.; Anderson, G.L. The women's health initiative: Lessons learned. Annu. Rev. Public Health 2008, 29, 131-150. [CrossRef] [PubMed]

97. Chlebowski, R.T.; Chen, Z.; Cauley, J.A.; Anderson, G.; Rodabough, R.J.; McTiernan, A.; Lane, D.S.; Manson, J.E.; Snetselaar, L.; Yasmeen, S.; et al. Oral bisphosphonate use and breast cancer incidence in postmenopausal women. J. Clin. Oncol. 2010, 28, 3582-3590. [CrossRef] [PubMed]

98. Coleman, R.; Powles, T.; Paterson, A.; Gnant, M.; Anderson, S.; Diel, I.; Gralow, J.; von Minckwitz, G.; Moebus, V.; Bergh, J.; et al. Adjuvant bisphosphonate treatment in early breast cancer: Meta-analyses of individual patient data from randomised trials. Lancet 2015, 386, 1353-1361. [CrossRef]

99. Biskup, E.; Cai, F.; Vetter, M. Bone targeted therapies in advanced breast cancer. Swiss Med. Wkly. 2017, 147, 1-11. [CrossRef]

100. Littlewood-Evans, A.J.; Bilbe, G.; Bowler, W.B.; Farley, D.; Wlodarski, B.; Kokubo, T.; Inaoka, T.; Sloane, J.; Evans, D.B.; Gallagher, J.A. The osteoclast-associated protease cathepsin K is expressed in human breast carcinoma. Cancer Res. 1997, 57, 5386-5390. [PubMed]

101. Le Gall, C.; Bellahcene, A.; Bonnelye, E.; Gasser, J.A.; Castronovo, V.; Green, J.; Zimmermann, J.; Clezardin, P. A Cathepsin K Inhibitor Reduces Breast Cancer Induced Osteolysis and Skeletal Tumor Burden. Cancer Res. 2007, 67, 9894-9902. [CrossRef] [PubMed]

102. Podgorski, I. Future of anticathepsin K drugs: Dual therapy for skeletal disease and atherosclerosis? Future Med. Chem. 2009, 1, 21-34. [CrossRef] [PubMed]

103. Jensen, A.B.; Wynne, C.; Ramirez, G.; He, W.; Song, Y.; Berd, Y.; Wang, H.; Mehta, A.; Lombardi, A. The cathepsin $\mathrm{k}$ inhibitor odanacatib suppresses bone resorption in women with breast cancer and established bone metastases: Results of a 4-week, double-blind, randomized, controlled trial. Clin. Breast Cancer 2010, 10, 452-458. [CrossRef] [PubMed]

104. Marzia, M.; Sims, N.A.; Voit, S.; Migliaccio, S.; Taranta, A.; Bernardini, S.; Faraggiana, T.; Yoneda, T.; Mundy, G.R.; Boyce, B.F.; et al. Decreased C-Src Expression Enhances Osteoblast Differentiation and Bone Formation. J. Cell Biol. 2000, 151, 311-320. [CrossRef] [PubMed] 
105. Myoui, A.; Nishimura, R.; Williams, P.J.; Hiraga, T.; Tamura, D.; Michigami, T.; Mundy, G.R.; Yoneda, T. C-Src tyrosine kinase activity is associated with tumor colonization in bone and lung in an animal model of human breast cancer metastasis. Cancer Res. 2003, 63, 5028-5033. [PubMed]

106. Rucci, N.; Recchia, I.; Angelucci, A.; Alamanou, M.; Del Fattore, A.; Fortunati, D.; Susa, M.; Fabbro, D.; Bologna, M.; Teti, A. Inhibition of protein kinase c-Src reduces the incidence of breast cancer metastases and increases survival in mice: Implications for therapy. J. Pharmacol. Exp. Ther. 2006, 318, 161-172. [CrossRef] [PubMed]

107. Lee, Y.C.; Huang, C.F.; Murshed, M.; Chu, K.; Araujo, J.C.; Ye, X.; Decrombrugghe, B.; Yu-Lee, L.Y.; Gallick, G.E.; Lin, S.H. Src family kinase/ABl inhibitor dasatinib suppresses proliferation and enhances differentiation of osteoblasts. Oncogene 2010, 29, 3196-3207. [CrossRef] [PubMed]

108. Rabbani, S.A.; Valentino, M.L.; Arakelian, A.; Ali, S.; Boschelli, F. SKI-606 (Bosutinib) blocks prostate cancer invasion, growth, and metastasis in vitro and in vivo through regulation of genes involved in cancer growth and skeletal metastasis. Mol. Cancer Ther. 2010, 9, 1147-1157. [CrossRef] [PubMed]

109. Yang, J.C.; Bai, L.; Yap, S.; Gao, A.C.; Kung, H.-J.; Evans, C.P. Effect of the specific Src family kinase inhibitor saracatinib on osteolytic lesions using the PC-3 bone model. Mol. Cancer Ther. 2010, 9, 1629-1637. [CrossRef] [PubMed]

110. Maroni, P.; Bendinelli, P.; Matteucci, E.; Locatelli, A.; Nakamura, T.; Scita, G.; Desiderio, M.A. Osteolytic bone metastasis is hampered by impinging on the interplay among autophagy, anoikis and ossification. Cell Death Dis. 2014, 5, e1005. [CrossRef] [PubMed]

111. Carter, R.Z.; Micocci, K.C.; Natoli, A.; Redvers, R.P.; Paquet-Fifield, S.; Martin, A.C.B.M.; Denoyer, D.; Ling, X.; Kim, S.H.; Tomasin, R.; et al. Tumor but not stromal expression of $\beta 3$ integrin is essential, and is required early, for spontaneous dissemination of bone-metastatic breast cancer. J. Pathol. 2015, 235, 760-772. [CrossRef] [PubMed]

112. Gramoun, A.; Shorey, S.; Bashutski, J.D.; Dixon, S.J.; Sims, S.M.; Heersche, J.N.M.; Manolson, M.F. Effects of Vitaxin ${ }^{\circledR}$, a novel therapeutic in trial for metastatic bone tumors, on osteoclast functions in vitro. J. Cell. Biochem. 2007, 102, 341-352. [CrossRef] [PubMed]

113. Zhao, Y.; Bachelier, R.; Treilleux, I.; Pujuguet, P.; Peyruchaud, O.; Baron, R.; Clément-Lacroix, P.; Clézardin, P. Tumor $\alpha v \beta 3$ integrin is a therapeutic target for breast cancer bone metastases. Cancer Res. 2007, 67, 5821-5830. [CrossRef] [PubMed]

114. Baron, R.; Kneissel, M. WNT signaling in bone homeostasis and disease: From human mutations to treatments. Nat. Med. 2013, 19, 179-192. [CrossRef] [PubMed]

115. Suen, P.K.; Qin, L. Sclerostin, an emerging therapeutic target for treating osteoporosis and osteoporotic fracture: A general review. J. Orthop. Transl. 2016, 4, 1-13. [CrossRef]

116. Mendoza-Villanueva, D.; Zeef, L.; Shore, P. Metastatic breast cancer cells inhibit osteoblast differentiation through the Runx2/CBF $\beta$-dependent expression of the Wnt antagonist, sclerostin. Breast Cancer Res. 2011, 13, R106. [CrossRef] [PubMed]

117. Kyvernitakis, I.; Rachner, T.D.; Urbschat, A.; Hars, O.; Hofbauer, L.C.; Hadji, P. Effect of aromatase inhibition on serum levels of sclerostin and dickkopf-1, bone turnover markers and bone mineral density in women with breast cancer. J. Cancer Res. Clin. Oncol. 2014, 140, 1671-1680. [CrossRef] [PubMed]

118. McClung, M.R.; Grauer, A.; Boonen, S.; Bolognese, M.A.; Brown, J.P.; Diez-Perez, A.; Langdahl, B.L.; Reginster, J.-Y.; Zanchetta, J.R.; Wasserman, S.M.; et al. Romosozumab in postmenopausal women with low bone mineral density. N. Engl. J. Med. 2014, 370, 412-420. [CrossRef] [PubMed]

119. Recker, R.R.; Benson, C.T.; Matsumoto, T.; Bolognese, M.A.; Robins, D.A.; Alam, J.; Chiang, A.Y.; Hu, L.; Krege, J.H.; Sowa, H.; et al. A randomized, double-blind phase 2 clinical trial of blosozumab, a sclerostin antibody, in postmenopausal women with low bone mineral density. J. Bone Miner. Res. 2015, 30, $216-224$. [CrossRef] [PubMed]

120. Reagan, M.R.; McDonald, M.; Terry, R.; Pettitt, J.; Le, L.; Mohanty, S.; Kneissel, M.; Kramer, I.; Brooks, D.; Bouxsein, M.; et al. Anti-sclerostin treatment prevents multiple myeloma induced bone loss and reduces tumor burden. Blood 2015, 126, 119. 